\title{
ゾルーゲル法によるリチウムー次電池用二酸化マンガンの合成
}

\author{
宮本 信明*, 北原 里美, 松藤誉梨子, 森田 玲子 \\ 有明工業高等専門学校物質工学科（二 836-8585 大车田市東萩尾町 150 番地）

\section{Synthesis of Manganese Dioxide by Sol-Gel Method for Lithium Primary Cells}

\author{
Nobuaki MiYAmoto, ${ }^{*}$ Satomi KITAhARA, Yoriko MATSUfUJI, and Reiko MorITA \\ Department of Chemical Science and Engineering, Ariake National College of Technology (150, Higashihagio- \\ machi, Omuta, Fukuoka 836-8585, Japan)
}

Received October 25, 1999 ; Accepted November 22, 1999

\begin{abstract}
Sodium manganese composite oxides were prepared by the sol-gel method using manganese acetate, sodium acetate and tartaric acid. Manganese dioxides were obtained by extraction of sodium ion from the composite oxides in nitric acid solution. It was confirmed from XRD patterns that $\gamma-\mathrm{MnO}_{2}$ phase was formed in low molar ratio $(\mathrm{Na} / \mathrm{Mn} \leqq 0.3)$ of sodium acetate to manganese acetate in starting materials, and the formation of $\alpha-\mathrm{MnO}_{2}$ phase was observed in a higher ratio. The specific surface areas were $230-240 \mathrm{~m}^{2} \mathrm{~g}^{-1}$. The discharge capacities of the products heated at $375^{\circ} \mathrm{C}$ as a cathode material in lithium/manganese oxide battery were $250-260 \mathrm{mAh} \mathrm{g}^{-1}$ regardless of $\mathrm{Na} / \mathrm{Mn}$ ratio. The capacities were higher than that of the electrolytic manganese dioxide (207 mAh. $\mathrm{g}^{-1}$ ). It was found that the composite oxide prepared using the sol-gel method is hopeful as a cathode material for lithium/manganese dioxide battery.
\end{abstract}

Key Words : Sol-Gel Method, Manganese Dioxide, Lithium Primary Cell

\section{1 緒 言}

金属酸化物の合成法の一つとしてゾルーゲル法がある。組 成が偏析せず均一な酸化物が比較的低温で得られ，微粒子で 比表面積が大きいことなどの特徴がある。マンガン化合物で はリチウム二次電池の正極活物質である $\mathrm{LiMn}_{2} \mathrm{O}_{4}$ の合成が 試みられ，従来法に比べて優れた電池性能を示すことが報告 されている ${ }^{1-3)}$ 二酸化マンガンについてもゾルーゲル法から の合成が行われているが，多くは出発物質として過マンがン 酸塩 $\mathrm{AMnO}_{4}\left(\mathrm{~A}=\mathrm{Li}^{+}, \mathrm{Na}^{+}, \mathrm{K}^{+}\right)$を用い，得られたゲル を乾燥後，焼成し，さらに酸処理することにより二酸化マン ガンを調製している ${ }^{4-6)}$.この方法では合成条件により $\lambda$, $\gamma, \delta$ 形など多くの結晶系の二酸化マンガンが生成し，優れた 電池性能のものも得られている。

前報てでは，二酸化マンガンと水酸化ナトリウムの混合物 を加熱して得たナトリウムーマンガン酸化物を硝酸溶液中に 添加することにより，電池性能に優れた $\gamma$ 形結晶の二酸化マ ンガンが生成することを明らかにした。このものの比表面積 は, 市販の電解二酸化マンガンよりも約 3 倍高い值を示した。 さらに比表面積が大きく, 電池性能に優れた二酸化マンガ ンを合成するために, 過マンガン酸塩を出発物質とする方法 とは異なるマンガン塩とナトリウム塩のアルコール溶媒の混 合液に酒石酸を添加するゾルーゲル法を試みた。本法ではマ ンガン塩として䣫酸マンガン, 酸には硝酸を用いた。出発物 質のマンガン塩とナトリウム塩のモル比を変えて調製した生 成物を正極活物質として用い，リチウムー二酸化マンガン一
次電池を試作し，電池性能を検討した。

\section{2 実 験}

出発物質には, 酢酸マンガン (II) 四水和物 $\left(\mathrm{Mn}\left(\mathrm{CH}_{3}\right.\right.$. $\left.\mathrm{COO})_{2} 4 \mathrm{H}_{2} \mathrm{O}\right)$, 酢酸ナトリウム $\left(\mathrm{CH}_{3} \mathrm{COONa}\right)$ と酒石酸 $\left(\mathrm{L}(+)-[\mathrm{CH}(\mathrm{OH}) \mathrm{COOH}]_{2}\right)$ の三種類の化合物を用いた。酢 酸マンガンに対する酶酸ナトリウムのモル比（以後 $\mathrm{Na} / \mathrm{Mn}$ 比と示す)を $0.0,0.3,0.5,1.0$ とした混合物をエタノール に溶解させ, 両者の合計モル数と同じ量の酒石酸を摚拌下で 添加することにより，ゲルを調製した。 その後，50Cで一日 保温することにより湿潤ゲルになり，さらに $150^{\circ} \mathrm{C} て ゙$ 加熱す ることにより乾燥ゲルが得られる。乾燥ゲルを $400^{\circ} \mathrm{C} て ゙ 5$ 時 間，空気を $50 \mathrm{dm}^{3} \mathrm{~h}^{-1}$ で流して加熱することによりナトり ウムーマンガン酸化物を合成した。

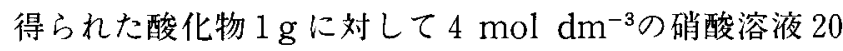
$\mathrm{cm}^{3}$ を共栓フラスコに添加し, $80^{\circ} \mathrm{C}$ で一昼夜静置する(以後酸 処理と記す)。その後ろ過, 水洗し, $80^{\circ} \mathrm{C}$ で乾燥した。さらに リチウムー二酸化マンガン電池の正極活物質として用いるた めに $375^{\circ} \mathrm{C}$ ，空気中で 5 時間加熱した。

乾燥ゲルの加熱温度を検討するため, 差動型示差熱天科 (TG-DTA；理学電機製，TG 8120) を用いた，なお，昇温

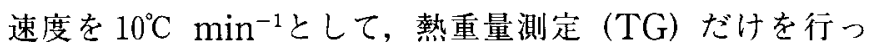
た. 生成物の同定は粉末 X 線回折装置 (XRD ; 島津製作所 製，XRD 6000)で行った。 また，走査型電子顕微鏡 (SEM ; 日立製作所製，S-3000 N) を用いて形態観察した．生成物の 
比表面積は，試作装置を用い BET 法で測定した。

正極合剤には, 活物質 : $25 \mathrm{mg}$, グラファイト : $4 \mathrm{mg}$, ア セチレンブラック : $4 \mathrm{mg}$, テフロン粉末 $: 6 \mathrm{mg}$ とし,これ らをニッケルメッシュ上に圧着したものを用いた，負極には 金属リチウム板を使用した，電解液は $\mathrm{PC}$ (炭酸プロピレン) と DME (1,2-ジメトキシエタン)の体積比 1:1 混合溶媒の $1 \mathrm{~mol} \mathrm{dm}^{-3}$ 過塩素酸リチウム溶液を用いた。電流密度を $0.44 \mathrm{~mA} \mathrm{~cm}^{-2}$ とし, 下限電圧 $2.0 \mathrm{~V}$ まで定電流放電を行っ た，比較として電解二酸化マンガン $(\mathrm{EMD}$, 国際共通二酸化 マンガン試料 No.17) を $375^{\circ} \mathrm{C} て ゙$ 加熱したものについても同 様に行った。

\section{1 二酸化マンガンの調製}

\section{3 結果と考察}

乾燥ゲルの加熱温度を決めるために, 乾燥ゲルの TG 測定 を行った. Fig. 1 に出発物質中の $\mathrm{Na} / \mathrm{Mn}$ 比 0.5 とした乾燥 ゲルと酶酸マンガン及び酒石酸の TG 曲線を示す。眽酸マン ガンの結晶水は $150^{\circ} \mathrm{C}$ までに脱離し，さらに約 $200^{\circ} \mathrm{C}$ で眽酸 オンの分解が始まり， $500^{\circ} \mathrm{C}$ では $68.6 \%$ の重量減少率に達し， $\mathrm{Mn}_{3} \mathrm{O}_{4}$ が生成していると考えられる。酒石酸も約 $200^{\circ} \mathrm{C}$ から 分解が始まり, $300^{\circ} \mathrm{C}$ では水と二酸化炭素に洼とんど分解し消 失している，上記の結果より，乾燥ゲルでは $200^{\circ} \mathrm{C}$ から酒石

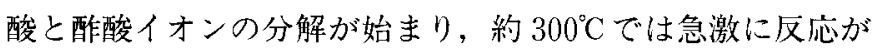
進み, $400^{\circ} \mathrm{C}$ で一定值に達していることから分解反心は完結し ていると考えられる。このことょり，乾燥ゲルの加熱温度は $400^{\circ} \mathrm{C}$ と, 以後の実験を行った。

Fig. 2 に出発物質中の $\mathrm{Na} / \mathrm{Mn}$ 比を $0.0,0.3,0.5,1.0$ と して得た乾燥ゲルの加熱生成物の X 線回折図を示寸. Na/ $\mathrm{Mn}$ 比 0.0 (出発物質として醀酸マンガンだけ)では, $\mathrm{Mn}_{3} \mathrm{O}_{4}$ の回折ピークだけが認められるが，0.3では $\mathrm{Na}_{4} \mathrm{Mn}_{14} \mathrm{O}_{27}$ $9 \mathrm{H}_{2} \mathrm{O}$ と $\mathrm{Na}_{2} \mathrm{Mn}_{5} \mathrm{O}_{10}$ のピークが現れ，0.5では $\mathrm{Na}_{2} \mathrm{Mn}_{5}$ $\mathrm{O}_{10}$ のピークは消失し, 新たに $\mathrm{Na}_{0.70} \mathrm{MnO}_{2.05}$ のピークが認め られた。さらに 1.0 になると, $\mathrm{Na}_{4} \mathrm{Mn}_{14} \mathrm{O}_{27} 9 \mathrm{H}_{2} \mathrm{O}$ のピーク は消失し, $\mathrm{Na}_{0.70} \mathrm{MnO}_{2.05}$ のピーク強度が増すことが確認さ れた。

著者ら》は，水酸化ナトリウムと二酸化マンガンの Na/ $\mathrm{Mn}$ 比 0.25 での混合物を $300^{\circ} \mathrm{C}$ で加熱すると $\mathrm{Na}_{4} \mathrm{Mn}_{14} \mathrm{O}_{27}$ $9 \mathrm{H}_{2} \mathrm{O}$ が, 0.75 では $\mathrm{Na}_{0.70} \mathrm{MnO}_{2.05}$ が生成することを確認し

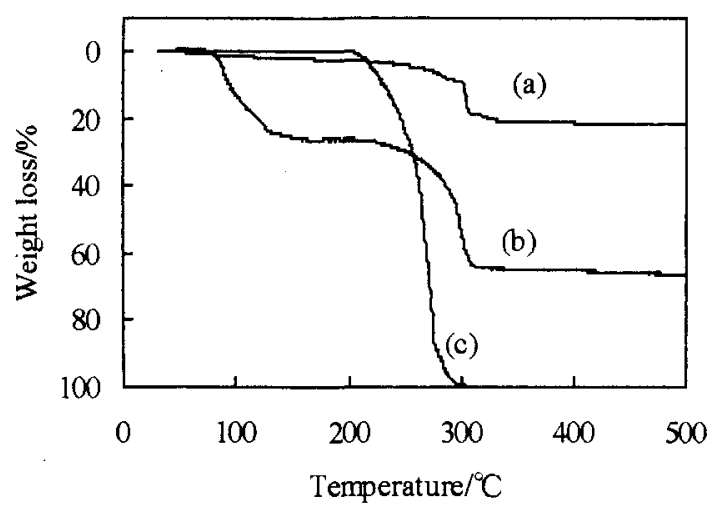

Fig. 1 Thermogravimetric analysis for (a) gel dried at $150^{\circ} \mathrm{C}$ with $\mathrm{Na} / \mathrm{Mn}$ ratio* of 0.5 , (b) manganese acetate and (c) tartaric acid. Heating rate: $10^{\circ} \mathrm{C} \min ^{-1}$.

* The molar ratio of sodium acetate to manganese acetate.

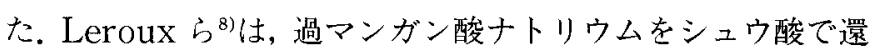
元する方法から $\mathrm{Na}_{4} \mathrm{Mn}_{9} \mathrm{O}_{18}, \mathrm{Na}_{0.70} \mathrm{MnO}_{2.05}$ などのナトリ ウムーマンガン酸化物が生成することを確認している．合成 法の違いによらず, 出発物質中の $\mathrm{Na} / \mathrm{Mn}$ 比が 0.5-1.0 と高 くなると $\mathrm{Na}_{0.70} \mathrm{MnO}_{2.05}$ が生成することが分かった。

次に酸処理物の X 線回折図を比較のための EMD と併せ て Fig. 3 に示寸. $\mathrm{Na} / \mathrm{Mn}$ 比 0.0 からのものは EMD と同 ビパターンを示し， $\gamma$-二酸化マンガンの結晶を有していると 考之られる。 0.5 では $\gamma$ 形結晶のピークは消失し， $\alpha$-二酸化 マンガンだけのピークが認められた。さらに $\mathrm{Na} / \mathrm{Mn}$ 此が増 加すると， $\alpha$ 形のピーク強度は增大する. $\mathrm{Na} / \mathrm{Mn}$ 比 0.3 は $\alpha$ 形結晶の（110)，(200）面の回折ピークが確認される.

方, $\gamma$ 形結晶の (221) 面の回折ピークも示されていることか ら，両結晶が混在していると考えられる。

な㧍, 上記した $\alpha$ 形結晶の回折パターンは, Miyazaki'の 過マンガン酸カリウムをフマール酸で還元して得た $900^{\circ} \mathrm{C}$ 焼 成物を硫酸で処理したもの（バーネサイト構造）とは明らか に異なる.一方, Thackeray ${ }^{93}$ が報告している $\alpha$-二酸化マン

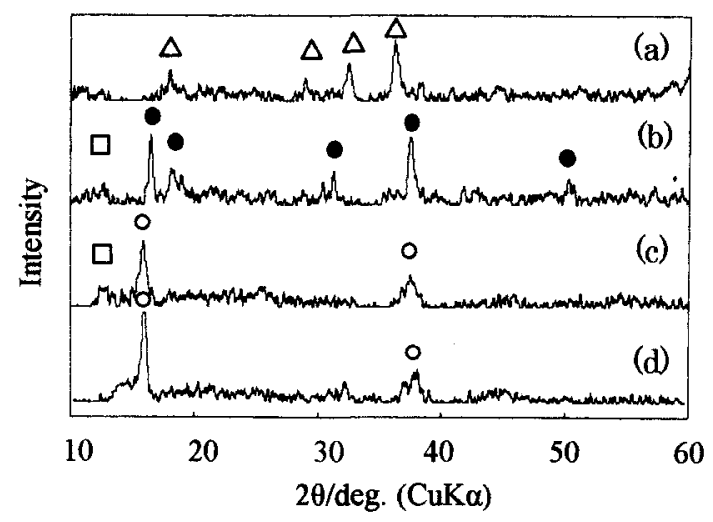

Fig. 2 X-ray diffraction patterns of the heated products with different $\mathrm{Na} / \mathrm{Mn}$ ratios in starting materials.

(a) $\mathrm{Na} / \mathrm{Mn}=0.0$, (b) $\mathrm{Na} / \mathrm{Mn}=0.3$, (c) $\mathrm{Na} / \mathrm{Mn}=0.5$, (d) Na/ $\mathrm{Mn}=1.0$.

: $\mathrm{Na}_{2} \mathrm{Mn}_{5} \mathrm{O}_{10}, \bigcirc: \mathrm{Na}_{0.70} \mathrm{MnO}_{2.05}, \square: \mathrm{Na}_{4} \mathrm{Mn}_{14} \mathrm{O}_{27^{-}}$ $9 \mathrm{H}_{2} \mathrm{O}, \triangle: \mathrm{Mn}_{3} \mathrm{O}_{4}$.

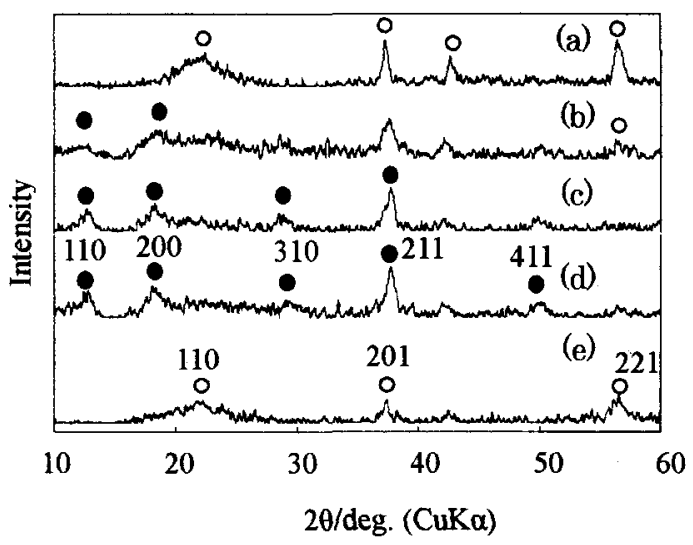

Fig. 3 X-ray diffraction patterns of the products by acid treatment (4 mol dm ${ }^{-3} \mathrm{HNO}_{3}$ soln.).

(a) $\mathrm{Na} / \mathrm{Mn}=0.0$, (b) $\mathrm{Na} / \mathrm{Mn}=0.3$, (c) $\mathrm{Na} / \mathrm{Mn}=0.5$, (d) $\mathrm{Na}$ / $\mathrm{Mn}=1.0$, (e) EMD.

$0: \gamma-\mathrm{MnO}_{2}, \boldsymbol{O}: \alpha-\mathrm{MnO}_{2}$.

Numbers over the peaks are hkl values. 
ガンの回折パターンとはほぼ同じであった。

\section{2 二酸化マンガンの特性}

Fig. 4 に出発物質中の $\mathrm{Na} / \mathrm{Mn}$ 比 1.0 の加熱生成物とそ の酸処理物の SEM 写真を示す. $\mathrm{Na} / \mathrm{Mn}$ 比による粒子形状 の違いは明確には認められず，一次粒子が集合して二次粒子

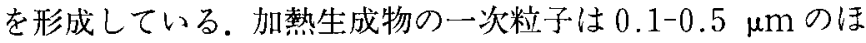
ぼ球形をしているが, 酸処理後は針状結晶が粒子表面を覆つ ていることが確認された。

酸処理物の表面積を測定した結果, 本法では $\mathrm{Na} / \mathrm{Mn}$ 比 0.0-1.0の範囲で 230-240 $\mathrm{m}^{2} \mathrm{~g}^{-1}$ と変動幅が小さく, EMD $\left(37 \mathrm{~m}^{2} \mathrm{~g}^{-1}\right)$ に比べて約 6 倍高い值を示すことが分かった. この值は，二酸化マンガンと水酸化ナトリウムを出発物質と した酸处理物 ${ }^{7} の$ 比表面積 90-110 $\mathrm{m}^{2} \mathrm{~g}^{-1}$ よりも高い.また, Miyazaki6)のゾルーゲル法から得られた二酸化マンガン $\left(200 \mathrm{~m}^{2} \mathrm{~g}^{-1}\right)$ よりも高い值である.

ゾルーゲル法から合成したものの一次粒子の大きさは0.01
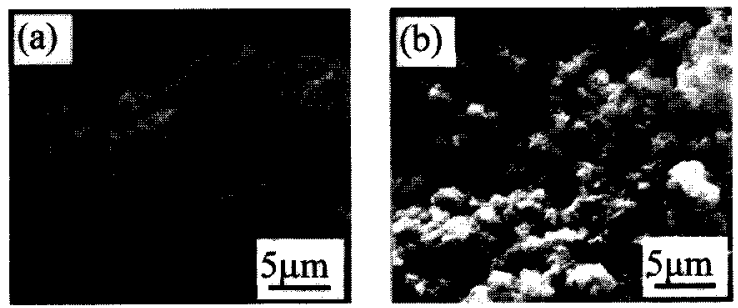

Fig. 4 Scanning electron micrographs for (a) the heated product with $\mathrm{Na} / \mathrm{Mn}$ ratio of 1.0 and (b) the product prepared by acid treatment of (a).

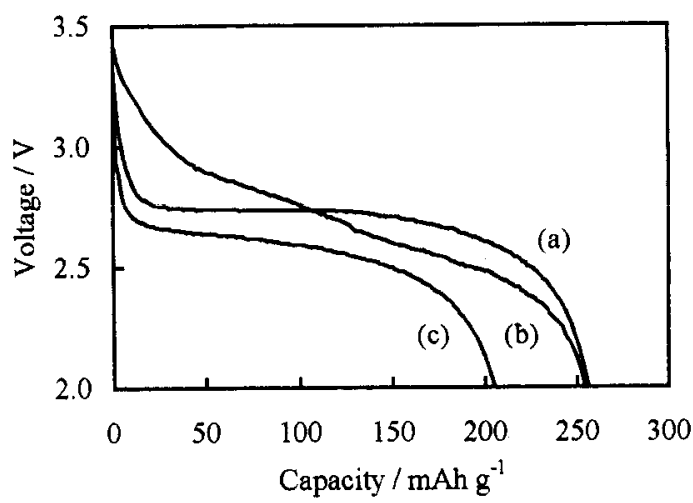

Fig. 5 Discharge curves $\left(0.44 \mathrm{~mA} \mathrm{~cm}^{-2}\right)$ for the products prepared at different ratios of $\mathrm{Na} / \mathrm{Mn}$ in starting materials. Electrolyte: $1 \mathrm{~mol} \mathrm{dm}{ }^{-3} \mathrm{LiClO}_{4} / \mathrm{PC}+\mathrm{DME}(1 / 1$ by volume).

(a) $\mathrm{Na} / \mathrm{Mn}=0.0$, (b) $\mathrm{Na} / \mathrm{Mn}=1.0$, (c) $\mathrm{EMD}$.
-0.1 $\mu \mathrm{m}$ オーダと小さいために, 平均粒子径が $10 \mu \mathrm{m}$ オー ダの $\mathrm{EMD}$ 及び $\mathrm{CMD}^{10)}$ (化学調製二酸化マンガン)に比べて 大幅に高い比表面積を示すと考えられる。

\section{3 . 3 電池特性}

酸処理物を正極活物質として用いたリチウム一次電池の放 電曲線を Fig. 5 に示す.横軸は単位重量当たりの容量を示し ている.本法の全ての生成物について, EMD を用いたものに 比べ $20 \%$ 以上高い容量 $\left(250-260 \mathrm{mAh} \mathrm{g}^{-1}\right)$ を示した。 $\mathrm{Na} /$ Mn 比 0.0では, 2.75-2.65 V において平坦な電压を示して いる. $\mathrm{Na} / \mathrm{Mn}$ 比が増加するにつれ，放電初期の電圧が高く なり，放電曲線は S 字カーブを描くことが認められた.この ような傾向は Thackeray ${ }^{9)}$ が報告している $\alpha$-二酸化マンガ ンを用いたりチウム電池においても見られる.

過マンガン酸塩を出発物質としたゾルーゲル法で得られた 二酸化マンガンも，リチウム電池用 ${ }^{11}$ 及びアルカリ電池用 ${ }^{6} の$ 正極活物質として，優れた特性を示している。この優れた性 能を示す理由として，ゾルーゲル法に共通な特徵である，微 粒子で比表面積が大きいことが上げられる，放電電流密度が 高くなるほど，正極活物質の比表面積の放電容量に与之る影 響が大きくなることが報告されている ${ }^{10)}$.ゾルーゲル法から 得られる二酸化マンガンは大きな比表面積を有しており，大 電流を必要とするリチウム電池の用途に適していると考えら れる。

\section{文献}

1) Y-K. Sun, Solid State Ionics, 100, 115 (1997).

2) L. Hernan, J. Morales, L. Sanchez, and J. Santos, Solid State Ionics, 104, 205 (1997).

3) Y-S. Lee, K-S. Nahm, and Y-K. Sun, Solid State Ionics, 109, 285 (1998).

4) S. Bach, M. Henry, N. Baffier, and J. Livage, J. Solid State Chem., 88, 325 (1990).

5) J. P. Pereira-Ramos, R. Baddour, S. Bach, and N. Baffier, J. Solid State Chem., 94, 185 (1991).

6) K. Miyazaki, T. Kato, and S. Kumamoto, Fukuoka Univ. Rev. Tech. Sci, 58, 149 (1997).

7) 田辺伊佐雄, 宮本信明, 電気化学 (presently Electrochemistry), 57, 164 (1989).

8) F. Leroux and L. F. Nazar, Solid State Ionics, 100, 103 (1997).

9) M. M. Thackeray, Prog. Solid State Chem., 25, 1 (1997).

10）永浦 享, 永峰政幸, 宮本信明, 田辺伊佐雄, 電気化学 (presently Electrochemistry), 57, 313 (1989).

11) L. A. de Picciotto and M. M. Thackeray, Mat. Res. Bull., 21, 583 (1986). 